
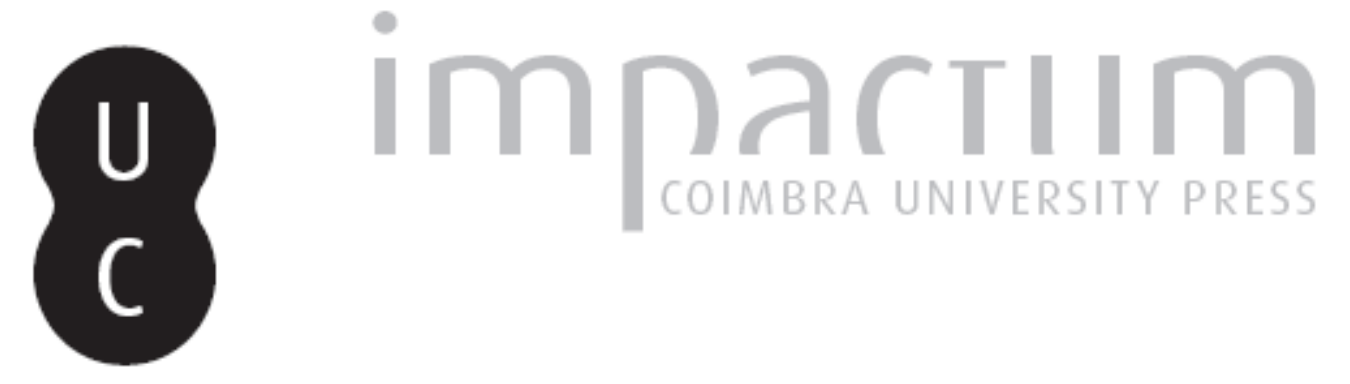

Para um estudo da posteridade do Futurismo na poesia portuguesa contemporânea Autor(es): $\quad$ Martinho, Fernando J. B.

Publicado por: Imprensa da Universidade de Coimbra

URL persistente: URI:http://hdl.handle.net/10316.2/42579

DOI: $\quad$ DOI:https://doi.org/10.14195/0870-8584_4_10

Accessed : $\quad$ 26-Apr-2023 12:40:46

A navegação consulta e descarregamento dos títulos inseridos nas Bibliotecas Digitais UC Digitalis, UC Pombalina e UC Impactum, pressupõem a aceitação plena e sem reservas dos Termos e Condições de Uso destas Bibliotecas Digitais, disponíveis em https://digitalis.uc.pt/pt-pt/termos.

Conforme exposto nos referidos Termos e Condições de Uso, o descarregamento de títulos de acesso restrito requer uma licença válida de autorização devendo o utilizador aceder ao(s) documento(s) a partir de um endereço de IP da instituição detentora da supramencionada licença.

Ao utilizador é apenas permitido o descarregamento para uso pessoal, pelo que o emprego do(s) título(s) descarregado(s) para outro fim, designadamente comercial, carece de autorização do respetivo autor ou editor da obra.

Na medida em que todas as obras da UC Digitalis se encontram protegidas pelo Código do Direito de Autor e Direitos Conexos e demais legislação aplicável, toda a cópia, parcial ou total, deste documento, nos casos em que é legalmente admitida, deverá conter ou fazer-se acompanhar por este aviso. 


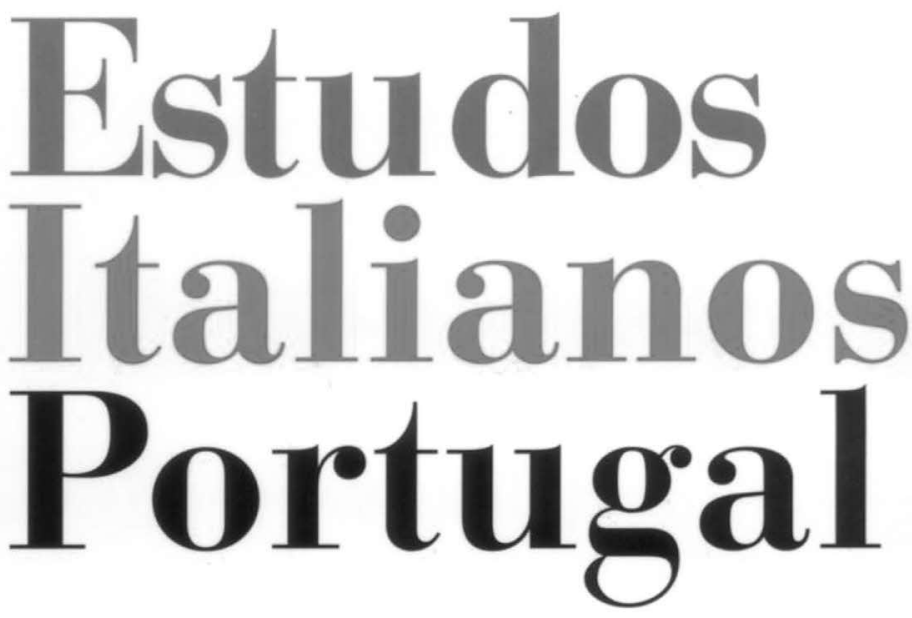

Instituto

Italiano

de Cultura

de Lisboa

Nova Série

$\mathbf{N}^{\mathbf{0}} 4$.

2009 


\title{
PARA UM ESTUDO DA POSTERIDADE DO FUTURISMO NA POESIA PORTUGUESA CONTEMPORÂNEA
}

\author{
Fernando J. B. Martinho
}

NÃo SE COMEMORA habitualmente o centenário de um movimento. O que se costuma fazer é, sim, celebrar o centenário do nascimento ou morte de autores. Como, no momento em que escrevo, se verifica com o bicentenário do nascimento de Poe. O que haverá, então, de especial na publicação em Fevereiro de 1909 do primeiro manifesto futurista, para, à sua volta, surgirem as iniciativas - exposições, colóquios, números especiais de revistas, etc. - que as grandes efemérides, em regra, motivam? A circunstância de ter sido o Futurismo a primeira das vanguardas novecentistas com um grande impacto e animada por um projecto que intentava abarcar todas as artes, poderá, de alguma forma, ajudar a explicar a presente comemoração. E também, certamente, o modelo que os seus textos manifestários, pela agressividade da linguagem e o gosto pela mais ruidosa das provocações, constituíram para as restantes vanguardas his-

* Professor aposentado da Faculdade de Letras da Universidade de Lisboa, onde se doutorou e leccionou, entre 1982 e 2004. Foi Leitor de Português nas Universidades de Bristol e de Santa Bárbara, na Califórnia. Publicou: Poesia - Resposta a Rorschach, 1970, e Razão Sombria, 1980. Ensaio - Pessoa e a Moderna Poesia Portuguesa, 1983; $2^{\text {a }}$ ed., 1991; Pessoa e os Surrealistas, 1988; Mário de Sá-Carneiro e o(s) Outro(s), 1990; Tendências Dominantes da Poesia Portuguesa da Década de 50, 1996. Coordenou e colaborou no volume Literatura Portuguesa do Século XX, Instituto Camões, 2004. 
tóricas terá tido algum peso nas celebrações a que vamos assistindo. Quererá isto dizer que o espírito iconoclasta das vanguardas ainda nos seduz, afinal, depois do rol de suspeitas que as últimas décadas, sob égide pós-modernista, lançaram sobre as grandes narrativas da modernidade? A verdade é que proclamações estrepitosas como as que inclui o manifesto publicado no Figaro em 1909 relativas ao propósito de destruir museus e bibliotecas não podem hoje deixar de nos fazer sorrir, depois da canonização de que foram objecto muitas das obras produzidas no âmbito do Futurismo. Já a glorificação da guerra, como "única higiene do mundo", defendida no mesmo texto, só pode causar-nos arrepios, testemunhas que temos sido de intermináveis conflitos num mundo que precisa de tudo menos de tão mortífero tratamento. Para não falar da tentação totalitária para que frequentemente resvalaram, na sua orientação totalizante, o Futurismo e as outras vanguardas históricas, sobretudo quando fizeram da praxis política o suporte maior da sua defesa da reintegração da arte na vida.

O período de vigência do Futurismo em Portugal é, como se sabe, curto, e a influência que o movimento teve na literatura posterior é, à primeira vista, reduzida e também relativamente limitada no tempo. Por outro lado, essa influência deverá, de algum modo, ser situada no quadro mais amplo da influência modernista, como bem observou Teolinda Gersão num dos textos introdutórios à reedição do Portugal Futurista ${ }^{1}$. Curiosamente, a referida estudiosa, a encerrar o seu texto, e para apoiar o entendimento que fazia da influência futurista como ligada à ou subsumível na influência modernista, socorria-se do testemunho de David MourãoFerreira, que reconhecia, num texto vindo a público em meados dos anos 60, em três colaboradores do Orpheu,

1 Cf. PORTUGAL Futurista - Edição Facsimilada, Lisboa, Contexto, 1981. Estudos prévios de Nuno Júdice e Teolinda Gersão, p. XXXIX. 
Pessoa, Sá-Carneiro e Almada, “os vultos tutelares da poesia do futuro" que era, então, o seu "presente"2. O que há de curioso no testemunho de Mourão-Ferreira é que ele era, à época, o representante de um sector de uma geração que estava bem longe do entendimento da modernidade como tabula rasa que era o do Futurismo e das outras vanguardas históricas, perspectivando antes a modernidade como thesaurus. Para além da óbvia impossibilidade de reduzir o Orpheu à vertente vanguardista do Modernismo (aí, se incluindo, evidentemente, o Futurismo), o que a posição de David Mourão-Ferreira, defensor de um entendimento dinâmico da tradição na sua harmonização com a modernidade, punha em evidência, ao reconhecer-se ele como herdeiro da transformação que aquela revista trouxera à poesia portuguesa, era a diversidade de veios que haviam convergido na definição de uma tradição lírica moderna em Portugal. Para a compreensão dessa tradição não poderá, no entanto, prescindir-se do contributo dado pelo Futurismo.

A cronologia que é incluída, na edição facsimilada do Portugal Futurista, em 1981, entre os dois textos introdutórios, abrange o período que se situa entre a publicação do texto de Marinetti "Fundação e Manifesto do Futurismo" no Figaro, em Paris, em 1909, o eco sem consequências de maior que essa publicação teve em dois jornais portugueses, um dos Açores e outro do Porto, logo nesse mesmo ano, e a sessão futurista no Teatro República em Abril de 1917, e a edição, alguns meses depois, de imediato, aliás, apreendida, do número único do Portugal Futurista. Nesta última data encerrava-se, poderíamos dizer, a fase heróica do Futurismo português, aquela em que tinham sido produzidos os textos fundamentais de Pessoa, Mário de Sá-Carneiro e Almada, mais ou menos enquadráveis no espírito do movimento, e o responsável, ou responsáveis, pela cronologia agia(m) sem

${ }^{2} I b .$, p. XXXIX. 
dúvida correctamente ao não ir além do ano de 1917. Neste trabalho, nos importa, todavia, sondar o que posteriormente na poesia portuguesa se pode, de alguma forma, reivindicar da herança futurista - e não é tão pouco como poderíamos ser levados a pensar -, não sem, naturalmente, colocar tais manifestações, num processo de mútua iluminação, em confronto com as que se constituíram como pontos de referência desse legado.

Que a memória do Futurismo e dos seus processos de afirmação permanecia viva prova-o a publicação em Coimbra, em 1925, de um manifesto subscrito por pseudónimos de quatro futuros colaboradores da presença, Mário Coutinho, Celestino Gomes, Abel Almada e António de Navarro. De onde lhes vem a inspiração pode ver-se claramente na passagem atribuível a António de Navarro, quando ele proclama: "Arte é movimento, é Universo dinâmico, é animismo veloz". Este mesmo poeta verá gorada, pouco depois, uma tentativa de realizar uma conferência no Teatro Sousa Bastos, muito em sintonia com o gosto dos vanguardistas pelas intervenções públicas sensacionalistas, pela performance. Terá experimentado então, porventura, a "volúpia de ser apupado", a que se referia Marinetti. Os ecos do escândalo gerado, dez anos antes, pelo Orpheu ainda não se tinham dissipado de todo, e os jovens que procuravam novos rumos em meados da década de vinte em Coimbra estavam bem a par de toda a efervescência de ideias estéticas que agitavam a cena cultural, como podia ver-se pelo capítulo dedicado ao Modernismo na tese de licenciatura que José Régio apresentou à Universidade local, no mesmo ano em que veio a público o Manifesto. Régio, que, aliás, não ocultou a sua indignação com a pateada que acolheu a conferência de $\mathrm{Navarro}^{3}$, deixará bem manifesta a sua familiaridade com a

Cf., F. J. Vieira, Pimentel, "Presença": Labor e Destino de uma Geração (1927-1940), Estudos e Ensaios, Coimbra, Angelus Novus, 2002, p. 24. 
estética futurista quando, a propósito da "fanfarra dos ismos", se refere a alguns dos princípios que a definiam, chegando mesmo a mencionar o nome de Marinetti como um dos nomes que "ficam de pé", no extenso ensaio que dá a lume, três anos depois, no $n^{\circ} 9$ da presença, "Literatura livresca e literatura viva": "O Futurismo exige a liberdade das palavras! proclama a pintura simultânea! magnifica o lirismo da força da saúde brutal, da alegria animal, da velocidade, do sol! [...] Da revoada de quantas escolas pretenderam descobrir a Arte, ficam de pé alguns nomes: como bandeiras! como lanças! [...] É Marinetti, com as suas páginas vertigínicas, a sua febre americana, o seu teatro sintético [...]"4. Se Régio jamais adequará a sua prática poética a essa estética, e mesmo Navarro, apesar de herdeiro do "veio mais anárquico" do nosso Primeiro Modernismo como observou Casais Monteiro $^{5}$, o mais próximo que esteve do Futurismo foi quando se identificou com a vertigem e o paroxismo que marcaram a geração dos loucos anos 20, em "Charleston", vindo a lume no n. ${ }^{\circ} 6$ da presença, em Julho de 1927: "O jazz/ zurze, risca, losangos, gumes,/ planos, ângulos, sonoros motes/ [...]”, é Gil Vaz, não obstante ser ele poeta geralmente avesso a ousadias vanguardistas, que parece estar mais perto, na revista de Coimbra $^{6}$, do espírito futurista, por via da celebração de um dos seus ícones mais conhecidos, num poema cujo título, "Marcha triunfal", ainda por cima, guarda a memória do título da Ode de Campos mais inegavelmente vinculada ao movimento iniciado por Marinetti em 1909: "Surge a locomotiva/Longa, omnipotente,/ Quantas rodas em rodopio!/ Hálito quente e frio,/ Metais em carne viva...// Depressa/

${ }^{4}$ J. Régio, Páginas de Doutrina e Crítica da "presença", Porto, Brasília Editora, 1977, pp.61-62.

5 Cf. A. Casais, Monteiro, O que foi e o que não foi o movimento da "presença", org., prefácio e notas de Fernando J.B. Martinho, Lisboa, Imprensa Nacional-Casa da Moeda, 1995, p. 129.

${ }^{6}$ N. ${ }^{\circ} 14$ e $15,23-7-1928$. 
Começa/ A fugir, fustigante, felina./ Duas nódoas de fogo à frente,/ Tudo em jogo:/ Ferro, aço, carvão, destroços e resina.// Mas, enquanto isto digo,/ Não consigo/ Traduzir o relâmpago, a vertigem/ De tal velocidade!/ Mas tal e qual suponho,/ Um instante de sonho/ Fugitivo...// Forte, febril, fervente, este phallus de ferro fura o espaço". Com efeito, encontramos aqui a celebração de uma "nova beleza", "a beleza da velocidade" proclamada pelos manifestos futuristas, e centrada, na circunstância, na locomotiva que, conforme dizia Marinetti no manifesto inaugural", "de peito amplo [...] atropela[...] os carris", ou a ela, num outro texto, se referia como "a bela máquina de aço que tantas vezes tinha brilhado de volúpia sob a [...] carícia [ do maquinista ]"8. Se pela entrega ao "novo sentimento mecânico"9 em "Marcha triunfal" Gil Vaz parecia identificar-se com a estética marinettiana, já na aceitação do espartilho da rima ${ }^{10}$ dela inequivocamente se afastava. Não deixe, no entanto, de sublinhar-se a diferença de caracteres no verso final do poema com vista a acentuar a sua "força expressiva", mesmo que, provavelmente, seja da responsabilidade da própria "folha de arte e crítica", como é sabido, muito sensível, por esse lado, à "revolução tipográfica" de que o Futurismo fez um dos seus cavalos-de-batalha.

Dois anos depois da publicação do poema de Gil Vaz, deparamos, nas páginas da presença ${ }^{11}$, com uma irónica charge de Edmundo de Bettencourt a Marinetti, ao seu apoio a Mussolini e à sua entrada na Academia, "Marinetti, e a anedota do iberismo fascista-futurista". A traição ao anti-academismo tantas vezes proclamado que a entrada de Marinetti na Aca-

7 Cf. Antologia do Futurismo Italiano - Manifestos e Poemas, org., tradução, introdução e notas de José Mendes Ferreira, Lisboa, Vega, 1979, pp. 50-51.

8 Ib., p. 82.

9 Cf. $i b .$, p. 124.

10 Cf. ib., p. 134.

${ }^{11}$ N. ${ }^{\circ}$ 24, Janeiro de 1930. 
demia significou motivara, no ano anterior, a Campos um dos seus mais lúcidos e amargos desabafos: "Lá chegam todo, lá chegam todos.../ Qualquer dia, salvo venda, chego eu também.../ Se nascem, afinal, todos para isso...// Não tenho remédio senão morrer antes,/ Não tenho remédio senão escalar o Grande Muro.../ Se fico cá, prendem-me para ser social...// Lá chegam todos, porque nasceram para isso,/ E só se chega ao Isso para que se nasceu...// Lá chegam todos.../ Marinetti, académico...// As Musas vingaram-se com focos eléctricos, meu velho,/ Puseram-te por fim na ribalta da cave velha,/ E a tua dinânica, sempre um bocado italiana, $\mathrm{f}-\mathrm{f}-\mathrm{f}-\mathrm{f}-\mathrm{f}-\mathrm{f}-\mathrm{f}-\mathrm{f}$.......". Por detrás da ironia de Campos está o profundo desapontamento de quem, apesar das múltiplas proclamações tendentes a marcar a sua distância em relação ao Futurismo, tinha consciência de que por lá também passara, e que, ainda não havia muito, mais concretamente nos fins de 1924 e nos começos de 1925, fizera alicerçar a sua estética não-aristotélica "não na ideia de beleza, mas na de força", e que, um dia, teve mesmo no horizonte de uma sua conhecida comparação ("O binómio de Newton é tão belo como a Vénus de Milo") a que Marinetti fizera no primeiro manifesto ("Um automóvel que ruge, que parece correr debaixo de fogo, é mais belo do que a Vitória de Samotrácia”).

A vinda a Portugal de Marinetti em 1932 e uma sessão realizada na Sociedade Nacional de Belas-Artes, onde o escritor italiano aparecia rodeado pelos "três mais categorizados inimigos do Futurismo em Portugal, Dr. Júlio Dantas, Adães Bermudes e o jornalista António Ferro", levariam Almada Negreiros a lembrar, num artigo vindo a público no Diário de Lisboa de 25 de Novembro $^{12}$, que ainda havia no País quem se mantivesse fiel aos princípios do Futurismo e permanecesse vigilante na "guerra sem tréguas contra putrefactos e botas de elástico". A Almada doía sobretudo a

12 Almada Negreiros, Textos de Intervenção, Lisboa, Estampa, 1972, pp. 135-137. 
amnésia de Marinetti relativamente aos que se tinham empenhado na aventura futurista em Portugal, "o único país latino, além da própria Itália”, onde o movimento se afirmara, e o ver "o admirável criador do Futurismo" acompanhado "pelos austeros 'pompiers' nacionais". O texto faz recordar aqui e além a verve incisiva e demolidora dos manifestos do período heróico, como quando, no final, deseja "uma feliz viagem de regresso" a Marinetti, depois do lamentável espectáculo que, entre nós, oferecera da sua decadência: "Lastimamos, nós os futuristas portugueses, que o grande cosmopolita Sr. Marinetti tenha por desgraça o grande e imparável defeito de não saber viajar, pelo menos em Portugal! // Para terminar, nós os futuristas portugueses, saudamos com o maior dos entusiasmos o sempre novo criador do futurismo nesta sua paragem pela capital da nossa grande terra, e desejamos-lhe uma feliz viagem de regresso à sua grande pátria, onde o espera o seu lugar bem merecido de académico do fáscio italiano". O amnésico e académico Marinetti não era, porém, o único alvo a atingir. Também António Ferro estava na mira de Almada. Quanto a Júlio Dantas, já tivera, em devido tempo, a sua conta, embora um estouvado futurista de Coimbra, Francisco Levita, não se tivesse coibido de, num manifesto intitulado Negreiros-Dantas, mimosear Almada com a ousada boutade de ser o "Dantas n. 2" ao ocupar-se de uma "banalidade" tão óbvia como o Dantas ${ }^{13}$. Sobre Ferro, o jornalista quase em vésperas de assumir a direcção do Secretariado de Propaganda Nacional, fazia Almada incidir o seu olhar crítico, por, ao participar no "ameno sarau mundano" que tivera lugar na Sociedade Nacional das Belas-Artes, estar a cumprir "exactamente os seus deveres com o seu programa pessoal”. As alusões, no artigo, à "Política do Espírito" não

$13 \mathrm{O}$ manifesto vem reproduzido num artigo de Rita Marnoto em $A$ Cidade - Revista Cultural de Portalegre, n. ${ }^{\circ} 9$ [ Nova Série ], 1994, pp. 7-21. Agora pode ser lido em R. Marnoto, Negreiros-Dantas uma página para a história da literatura nacional ..., Porto, Fenda, 2009. 
têm, aliás, outro intuito senão pôr em evidência que Ferro não tinha dado, com a sua participação na sessão, o melhor uso a essa política de que se mostrara o arauto num texto vindo a público nesse mesmo ano no Diário de Notícias $^{14}$, e mais não fizera, afinal, do que "estar subordinado às habilidades e caprichos mundanos do [seu] pessoalíssimo programa". A dureza de Almada para com António Ferro era, obviamente, a de quem não esquecia o companheiro dos tempos do Orpheu, o modernista que pronunciara em 1922, no Brasil, a conferência $A$ Idade do Jazz-Band, onde, muito ao jeito dos manifestos futuristas, proclamava uma funda sintonia com a sua "Época" e manifestava o seu repúdio pela saudade do passado ("Eu não compreendo, de modo algum, a saudade doentia de outras épocas, a nostalgia das idades mortas, certa ronda de fantasmas, lamurienta e sinistra que anda para aí - fox-trot de esqueletos mutilados...," 15 ), ou um dos representantes de uma "tradição viva" em luta contra o passadismo que o modernista francês Valery Larbaud, de visita a Portugal em 1926, distinguira na nossa jovem literatura de então ${ }^{16}$. De resto, até ao fim da vida Almada permaneceu fiel ao seu lema de uma "guerra sem tréguas contra putrefactos e botas de elástico"17, e, três anos depois, voltaria a pôr um ponto no $i$ do futurismo, em polémica com Dutra Faria, a propósito do comentário que este fizera, nas páginas do Fradique, sobre um seu texto comemorativo dos vinte anos da publicação do Orpheu, no suplemento literário do Diário de Lisboa. No artigo $^{18}$, vindo igualmente a lume neste jornal, Almada distancia-se claramente das posições de

14 Cf. Fernando Guedes, António Ferro e a sua Política do Espírito, Lisboa, Academia Portuguesa da História, 1997, p. 20.

15 António, Ferro, Intervenção Modernista - Teoria do Gosto, Lisboa, Verbo, 1987, p. 203.

16 Cf. Valery Larbaud, Jaune Bleu Blanc, Paris, Gallimard, 1991, pp. 256-257.

17 A. Negreiros, op. cit., p. 137.

18 Ib., pp. 187-190. 
Dutra Faria, a quem interessaria sobretudo o Marinetti político apoiante de Mussolini, e não tanto o Marinetti "revolucionário da Arte". É este que importa a Almada, que, numa postura típicamente modernista de defesa da autonomia da arte, reivindica a natureza "honradamente" literária do Orpheu, e manifesta uma inequívoca preferência pelo que chama o Marinetti I, o autor dos "memoráveis manifestos", e não pelo Marinetti II, o que se deixou engolir pelas exigências do fascismo italiano. Num outro texto ainda dentro da polémica com Dutra Faria ${ }^{19}$, Almada fará questão de sublinhar a insanável divergência "entre Arte e Política", acabando por, no que diz respeito à relação do artista com o mundo, dar razão aos Cubistas, por terem optado "pelos seus próprios ateliers para comunicar com o mundo, enquanto que os futuristas decidiram intervir directamente nos poderes públicos", vindo assim a submeter-se a desígnios "bem mais imediatos e ocasionais do que os da Arte". O que, aqui, porém, está em causa não é tanto a opção entre Cubismo e Futurismo, que serve, na circunstância, fins meramente argumentativos. O que há, sim, a reter é a fidelidade de Almada a uma arte do seu tempo, a sua escuta permanente do "grito" que a justifica, o grito, como dirá em texto dedicado a Amadeo, por ocasião de uma exposição retrospectiva do pintor de Amarante, em $1959^{20}$, que retira a sua legitimidade da não-aceitação do "rito".

Outro que também sabia que o grito é tanto mais legítimo quanto menos "aceitar o rito" era o seu companheiro dos tempos heróicos do Portugal Futurista, Raul Leal. Em fins dos anos 50, a sua fidelidade ao espírito do que chama o "movimento ultramodernista de Orpheu"21 vai, de algum

19 Ib., pp. 191-196.

20 Ib., pp. 223-225.

${ }^{21}$ Raul, Leal, "As tendências orfaicas e o Saudosismo", Tempo Presente Revista Portuguesa de Cultura, n 5, Setembro de 1959, p. 17. 
modo, estar na base da reabilitação a que se assiste da sua figura, com origem em diferentes quadrantes. Jorge de Sena, com a inclusão de poemas de sua autoria na $3^{a}$ série das Líricas Portuguesas, em 1958, faz justiça à incómoda singularidade da sua obra, que Cabral do Nascimento deixara de fora da 2. ' Série por ele organizada nos anos 40. Os surrealistas dão-lhe caloroso acolhimento no Café Gelo, vendo nele o símbolo da vertente mais iconoclasta do Primeiro Modernismo e o visionário que frequenta zonas próximas da surrealidade que têm como objectivo maior. Os responsáveis de Tempo Presente, por sua vez, dão lugar de destaque aos seus textos nas páginas da revista, porque nele reconhecem um representante do vanguardismo estético de que se reclamam e sentem o seu anarquismo de direita próximo do radicalismo doutrinário de pendor fascista que os distingue. Num artigo vindo a lume no n. 5 desta publicação, em Setembro de $1959^{22}$ Raul Leal evocará a carta que dirigiu, em 1921, a Marinetti em que se demarcava do que seria a "concepção da história" dos futuristas, por, em seu entender, ser "muito pouco futurista", e anunciava uma nova Religião e uma nova Igreja que teriam "tanto uma como outra um carácter distintamente futurista". A Igreja Paracletiana que anunciava, era, assim, "uma Igreja essencialmente Futurista"23. De acordo com a síntese que, nas páginas do Tempo Presente, faz da carta dirigida a Marinetti, o que o separava do "futurismo ortodoxo" era a importância que ele, Raul Leal, atribuía à “vida do Eu" e à "Vida do Espírito". Em sua opinião, contrariamente ao "futurismo ortodoxo", que as condenava, essas Vidas “podiam e deviam subsistir através das mais arro-

22 Raul, Leal, "As tendências orfaicas e o Saudosismo", Tempo Presente Revista Portuguesa de Cultura, $\mathrm{n}^{\circ}$ 5, Setembro de 1959, pp. 17-24.

${ }^{23}$ Leal, in Páginas de Estética e de Teoria e Crítica Literárias, (textos estabelecidos e prefaciados por Georg Rudolf Lind e Jacinto do Prado Coelho, Lisboa, Ática, $2^{a}$ ed., 1994, pp. 169-174) de F. Pessoa, a quem foi erradamente atribuída a carta a Marinetti. 
jadas realizações futuristas de forma que estas e todo o seu dinamismo intrínseco se animizassem, impregnando-se da mais alta espiritualidade, até mesmo mística"24. Haveria, pois, para ele, um défice espiritual no "futurismo ortodoxo". Por outro lado, relativamente às "criações antigas", objecto de violenta rejeição por parte de Marinetti, Raul Leal defendia que não se tratava de banir "em absoluto a alma" dessas criações, mas, antes, de a "actualizar", ou seja, "combiná-la, fundi-la com as tendências mais acentuadamente, mais extremamente modernistas". Isso mesmo, conforme explica logo a seguir, o terá levado a defender junto de Marinetti a "fusão absoluta, substancial [...] de todas as artes", que faz questão de distinguir da proposta wagneriana, situada ao nível da mera “justaposição". Às suas concepções dará ele o nome de "ultrafuturistas", por, infere-se, se situarem além do futurismo ortodoxo. Do mesmo modo alude, no artigo, ao Orpheu como "movimento ultramodernista". Mais, porém, que essa demarcação o singularizam os termos em que o faz, como quando, por exemplo, a propósito do "ultramodernismo orfaico", aponta a "excessividade delirante de vida espiritual, tornada espasmódica e alucinatória" como o elemento que mais poderosamente o caracteriza, ou quando se refere à fusão das artes, recorrendo a uma linguagem de expressiva desmesura, a vai figurar "torrencialmente lançada nos espaços duma forma puramente abstraccionante em Labirintizar - Vertigem sempre viva como gigantesco cenário -, força aérea em contínua convulsão mágica e delírio astral". Sem dificuldade se adivinha que foram este desregramento verbal e este metaforismo convulsivo que fascinaram os surrealistas nos anos 50 e o tornaram uma das figuras tutelares do Grupo do Gelo. Como logo em 1925 tinham seduzido um seu companheiro de fulgurantes excentricidades modernistas, Mário Saa, que, em $A$ Invasão dos Judeus, faz a sua exuberante celebração: 
"Ele anuncia o Reino da Metafísica, o vertigínico reino da Transcendência. Pretende-se o fundador duma nova religião do Divino Paráclito. Raul Leal é dos primeiros futuristas portugueses, mas é-o puramente, sem farisaísmo, como infelizmente não sucede à maior parte dos nossos artistas. Ele não é futurista, pois que é o próprio futurismo! Seus pensamentos têm profunda raiz na sensualidade extravagantemente musical. A sua metafísica é a confusão labiríntica dos sentidos, transcendência das paixões, o delírio da carne e da alma, o fluir e o refluir, o concentrar-se o Infinito em uma gota até essa gota se solver no Infinito" 25 .

Os poemas dimensionais de António Pedro, dados a conhecer em meados dos anos 30, alguma coisa devem a toda uma tradição vanguardista que realça o que Charles Siriato chamou, no "Manifeste Planiste", o "princípio da visualidade literária"26 , e para a qual os poemi paroliberi ${ }^{27}$ dos futuristas deram um impulso decisivo. O nome do fundador do Futurismo figura, aliás, entre os de um conjunto de personalidades que, como António Pedro dirá num texto autobiográfico de 1955, com ele tiveram "relações mais demoradas e mais amistosas que as do simples conhecimento ocasional" 28 , e o poeta português estava certamente a par da produção manifestária dos futuristas e das experiências por estes realizadas, designadamente no âmbito do paroliberismo ${ }^{29}$. O "Manifesto Dimensionista", que António Pedro subscreveu em Paris em

${ }^{25}$ Apud, Fernandes, in Raul Leal, Sodoma Divinizada, org., introdução e cronologia de Aníbal Fernandes, Lisboa, Hiena, 1989, pp. 128-129.

26 In António Pedro, Antologia Poética, introdução, selecção e notas de Fernando Matos Oliveira, Braga-Coimbra, Angelus Novus, 1998, pp. 104.

27 Cf. De Maria, in Art e Dossier, Inserto redazionale allegato al n. 2, Futurismo, Maggio 1986, pp. 52-53.

28 A. Pedro, in Catálogo de Exposição Retrospectiva de António Pedro, Câmara Municipal de Caminha, Centro de Arte Contemporânea, Porto, Fundação Calouste Gulbenlian, Lisboa, 1979, p. 56.

${ }^{29}$ Cf. De Maria, loc. cit. 
1935, a par de figuras como Alexander Calder, Duchamps, Arp, Miró, Kandinsky e Picabia, começava por apresentar o novo movimento como o ponto culminante de um processo iniciado por dois outros movimentos de vanguarda, o Cubismo e o Futurismo ${ }^{30}$, e proclamava, entre os seus princípios programáticos, o "desabar" de "todos os antigos limites e fronteiras das artes" 31 . Na conferência que pronuncia, em Junho de 1936, no âmbito da I Exposição de Artistas Modernos Independentes, e a que deu o título de De Marinetti aos Dimensionistas, Dutra Faria, que fora companheiro de António Pedro no seu período de adesão ao NacionalSindicalismo, em jornais como Acção Nacional e Revolução ${ }^{32}$, e que, como vimos, entrou em polémica com Almada no ano anterior, falará da necessidade de aplicar à arte o "princípio heraclitiano da identidade dos contrários", ou seja de deixar de encarar a poesia e a pintura "como pólos opostos" 33 . E citará mesmo, em abono da sua tese, uma passagem de uma conferência de Breton em Praga, em 1935, "Situation surréaliste de l'objet" ("pour ma part, je crois aujourd'hui à la possibilité et au grand interêt de l'expérience qui consiste à incorporer à un poème des objets usuels ou autres, plus exactement à composer un poème dans lequel des éléments visuels trouvent place entre les mots sans jamais faire double emploi avec eux”), para concluir que já então António Pedro "tomara a iniciativa e lançara a teoria daquilo a que chamou, primeiro do que qualquer outro, poesia dimensional - ou dimensionismo" "34. No "desvairo/ Impróprio para sone-

${ }^{30}$ In Pedro, Antologia..., cit., p. 98.

31 Ibid., p. 98.

32 Cf. França, in Catálogo Exposição Retrospectiva de António Pedro, cit, p. 43.

33 Dutra Faria, De Marinetti aos Dimensionistas: Conferência Lida na I Exposição dos Artistas Modernos Independentes em Junho de 1936, Lisboa, Edições Acção, 1936, p. 1936.

${ }^{34}$ Ibid., p. 20 
tos" a que se entrega num desses poemas dimensionais ${ }^{35}$, paira mesmo a memória dos versos graficamente ondeantes de "Manucure" de Mário de Sá-Carneiro, exemplo maior no âmbito do Futurismo português de aplicação da 'estética futurista', de celebração de uma nova Beleza, assente em "Números e letras, firmas e cartazes - / Altos-relevos, ornamentações!... - / Palavras em liberdade, sons sem-fio"36. António Pedro acabará por deixar, depois, o seu nome essencialmente ligado, enquanto escritor e pintor, ao Surrealismo, mas não pode esquecer-se o empenho que pôs num movimento como o Dimensionismo, que, em certos aspectos, é, como vimos, herdeiro do Futurismo. Não surpreende, assim, que E.M. de Melo e Castro venha, mais tarde, a reconhecer nos poemas dimensionais de António Pedro a condição de "precursores da poesia visual e experimental da década de 60 "37, e nos permita mesmo aproximar os "retratos metamíticos" que fez de quatro grandes figuras do nosso Primeiro Modernismo, Santa Rita Pintor, Mário de Sá-Carneiro, Pessoa e Almada ${ }^{38}$, da ligação que, em alguns dos poemas dimensionais do autor de 15 Poèmes au Hasard, se estabelece entre desenho e texto ${ }^{39}$.

No livro de estreia do neo-realista Joaquim Namorado, Aviso à Navegação, de 1941, o nexo com o Futurismo estabelece-se sobretudo através de Álvaro de Campos, com uma presença muito forte no intertexto da colectânea, a nível quer da epígrafe, quer da glosa ou ainda da adopção do verso livre. Nos poemas da terceira secção do volume, "Arqui-

35 Pedro, Antologia..., cit., p. 34.

36 Mário de Sá-Carneiro, Poemas Completos, ed. de Fernando Cabral Martins, Lisboa, Assírio \& Alvim, 1996, pp. 65-66.

37 E. M. de Melo e Castro, As Vanguardas na Poesia Portuguesa do Séc. XX, Lisboa, Instituto de Cultura e Língua Portuguesa, 1980, p. 65.

38 In Poemografias - Perspectivas da Poesia Visual Portuguesa, org. Fernando Aguiar e Silvestre Pestana, Lisboa, Ulmeiro, 1985, pp. 144-145.

39 Cf. Pedro, Antologia..., cit., 1998, pp. 39-42. 
tectura" ${ }^{40}$, posta sob a égide de Cesário, precursor assumido de Caeiro e Campos, o diálogo que mais nitidamente emerge é com o Campos da "Ode Triunfal", mas não é de descartar que Namorado, homem bem informado relativamente à tradição lírica moderna, estivesse a par das linhas essenciais do Futurismo, a que associa por mais de uma vez num artigo publicado em O Diabo, em Fevereiro de 1940, o heterónimo de Pessoa, que chega a encarar como sendo "talvez o único futurista português" 41 . Ao diálogo com o Futurismo, efectuado pela mediação de Campos, ou, quiçá, directamente, haveria que acrescentar o que se pode adivinhar que este poeta sensível à "beleza nova dos maquinismos" teria tido com um poeta como o oitocentista Guilherme de Azevedo, de quem cita, num artigo de 1945, um soneto de Alma Nova, que, pela "confiança" que manifesta no "grande desenvolvimento industrial" e pela "crença" que exibe "na ciência e no poder da técnica" ${ }^{2}$, poderia, sem dificuldade, figurar entre os precursores do nosso Futurismo: "Ó máquinas febris! Eu sinto a cada passo,/ Nos silvos que soltais, aquele canto imenso,/ Que a nova geração nos lábios traz suspenso/ Como a estância viril d'uma epopeia d'aço!// [...]”. Seja como for, a celebração que em alguns dos poemas da terceira secção de Aviso á Navegação se faz dos "motores", dos "volantes", das "máquinas", da "fábrica", e do "ritmo vertiginoso, alucinante" que anima todo esse universo fabril, está, no essencial, em consonância com os princípios enunciados num manifesto como "O homem multiplicado e o reino da máquina" 43 , onde se afirma "a ideia da beleza mecânica” e se exalta “o amor pela máquina”. A sintonia perfeita

40 Namorado, in Novo Cancioneiro, pref., org. e notas de Alexandre Pinheiro Torres, Lisboa, Caminho, 1989, pp. 199-203.

41 Joaquim Namorado, Obras. Ensaios e Críticas. I- Uma Poética da Cultura, org., prefácio e notas de António Pedro Pita, Lisboa, Caminho, 1994, p. 247.

42 Ib., pp. 254- 255.

43 Antologia dos Futuristas Italianos, cit., pp. 82-85. 
entre homem e máquina no breve poema que encerra a secção, "Condutores de máquinas" ${ }^{44}$, não anda longe do que se enuncia num parágrafo de um outro manifesto de Marinetti: "O homem multiplicado pela máquina. Novo sentimento mecânico, fusão do instinto com o rendimento do motor e com as forças amestradas". ${ }^{45}$ Citem-se, a encerrar esta referência ao autor de Aviso à Navegação, uma passagem de um poema ( "[...]// O grito das sirenes/ rasgou o silêncio da manhã clara.../ um ritmo novo/ acordou a cidade adormecida./ Ritmo que se grita/ nas alavancas que se movem, / nos êmbolos que chocam,/ nos martelos que retinem;/ ritmo mecânico, compassado,/ das hélices dos motores;/ ritmo vertiginoso, alucinante,/ dominante, dos volantes;/ ritmo novo dos corações,/ na canção ardente do trabalho!/ Ritmo de máquinas,/ de alavancas e de braços./ - Ritmo novo da manhã clara!", ${ }^{46}$ ) e um outro ( "Oh, a poesia de tudo o que é geométrico/ e perfeito,/ a beleza nova dos maquinismos, / a força secreta das peças/ sob o contacto frio e liso dos metais, / a segura confiança/ do saber-se que é assim e assim exactamente, / sem lugar a enganos, / tudo matemático e harmónico,/ sem nenhum imprevisto, sem nenhuma aventura,/ como na cabeça do engenheiro./ Os operários têm nos músculos, de cor,/ os movimentos dia a dia repetidos:/ é como se fossem da sua natureza,/ longe de toda a vontade e de todo o pensamento;/ como se os metais fossem carne do corpo/ e as veias se abrissem/ àquela vida estranha, dura, implacável/ das máquinas./ Os motores de tantos mil cavalos/ alinhados e seguros de si,/ seguros do seu poder;/ as articulações subtis das bielas, / o enlace justo das engrenagens:/ a fábrica, todo um imenso corpo de movi-

44 Joaquim Namorado, Aviso à Navegação, in Novo Cancioneiro, pref. org. e notas Alexandre Pinheiro Torres, Lisboa, Caminho, 1989, p. 203.

45 Antologia dos Futuristas Italianos, cit., p. 124.

46 Namorado, Aviso à Navegação, cit., p. 200. 
mentos/ concordantes, dependentes, necessários" ${ }^{47}$ ), em que fica patente o que Eduardo Lourenço, com a sua habitual argúcia, designou de "retórica tractorista" na poesia de Namorado, não sem, ao mesmo tempo, diga-se de passagem, salientar a novidade que essa poesia não deixava então de constituir $^{48}$.

Se é verdade que o diálogo com o Futurismo em Portugal se processou fundamentalmente através do Futurismo italiano, haverá, pelo menos, que colocar a hipótese de, muito pontualmente, esse diálogo ter passado também pelo Cubo-Futurismo russo. E poderá ser este o caso dos “Quatro sonetos a Afrodite Anadiómena" que Jorge de Sena publicou juntamente com Metamorfoses, em 1963. O que justificará a colocação desta hipótese são os pontos de contacto que é possível estabelecer entre as experiências dos futuristas russos no âmbito do que eles chamavam linguagem transmental e as experiências levadas a cabo por Sena nos referidos sonetos no sentido de as palavras deixarem de "significar semanticamente", de o poeta aí destruir a linguagem "como significação" 49 . Será, no entanto, conveniente desde logo esclarecer que, ao considerar a possibilidade de um influxo do Futurismo russo numa experiência que se assume como "uma tentativa para retomar em Ângelo de Lima [...] um dos cursos traídos do Modernismo português" ${ }^{50}$, não se está, de modo algum, a sugerir que seja esse o único ponto de mediação na relação que os textos estabelecem com toda uma tradição vanguardista que, de uma forma ou de outra, não se limite a "ampliar a linguagem corrente da poesia", e, antes, questione a própria linguagem. Pretende é chamar-

47 Ib., pp. 202-203.

48 Eduardo Lourenço, Sentido e Forma da Poesia Neo-Realista, Lisboa, Ulisseia, 1968, pp. 134-135.

49 Jorge de Sena, Poesia II, Lisboa, Moraes, 1978, pp. 164-165.

50 Ib., p. 165.

$51 \mathrm{Ib}$, .p. 165. 
se a atenção para as semelhanças existentes entre a poética de Sena tal como se apresenta no "Posfácio" ao livro de 1963 e algumas das linhas que definem a poética do CuboFuturismo russo, como quando, por exemplo, esta se afasta da do Futurismo italiano, ao rejeitar não apenas as convenções literárias anteriores mas a própria linguagem na sua condição corrente ${ }^{52}$. Assim Kruchenykh afirmará: "Para representar o novo, o futuro, são precisas palavras totalmente novas e um novo modo de as combinar" 53 . Quando Sena pretende que as "associações sonoras" que "compõem" as palavras nos sonetos representem "um complexo de imagens suscitadas à consciência liminar" "54, não anda muito longe da convicção dos futuristas russos de que a criação de novas palavras ou as manipulações efectuadas nas existentes e a sua combinação permitem não apenas alcançar uma maior "expressividade" como ainda "revelar sentidos ocultos, "primitivos' através das raízes esquecidas das palavras"55. A este respeito, é bem elucidativo o que Sena diz a propósito do último soneto, em que a maioria das palavras não seria propriamente inventada, correspondendo antes aos "epítetos gregos de Afrodite": "E creio ser curioso como, ligeiramente transformados na acentuação ( alguns ), igualmente contribuem para a criação de uma atmosfera erótica, concreta, cuja concretização não depende do sentido das palavras, mas da fragmentação delas integrada num sentido mais vasto, evocativo e obsessivo" 56 . Transcreva-se, então, o referido soneto, "Amátia": "Timbórica, morfia, ó persefessa,/ meláina, andrófona, repitimbídia,/ ó basilissa, ó scótia, masturlídia,/ amata cíprea, calipígea, tressa// de jardinatas nigras, pasi-

52 Cf. Peter Nicholls, Modernisms: a Literary Guide, London, MacMillan, 1995, pp. 127.

\footnotetext{
53 Apud ib., p. 127.

54 Cf. Sena, op.cit., p. 164.

55 Cf. Nicholls, op. cit., pp. 128-129.

56 Sena, op. cit., p. 165.
} 
fessa,/ luni-rosácea lambidando erídia,/ erínea, erítia, erótia, erânia, egídia,/ eurínoma, ambológera, donlessa.// Ares, Hefáistos, Adonísio, tutos/ alipigmaios, atilícios, futos/ da lívia damitada, organissanta,// agonimais se esgorem morituros, / necrotentavos de escancárias duros, / tantisqua abradimembra a teia canta" 57 .

O problema que, aqui, se levanta relativamente a possíveis cruzamentos entre um autor português, para o caso Jorge de Sena, e os cubo-futuristas russos, já foi também colocado a propósito de uma figura grada do nosso Primeiro Modernismo, Mário de Sá-Carneiro. Osvaldo Silvestre, na sua Tese de Mestrado, A Vanguarda na Literatura Portuguesa: o Futurismo, de 1990, chama a atenção para o paralelo que é possível estabelecer entre o Selvagismo que entusiasma um personagem de $A$ Confissão de Lúcio, Gervásio Vila-Nova, e identificado com um "poeta russo de nome arrevesado", e a linguagem transmental dos cubo-futuristas, embora tenha o cuidado de fazer notar que, ao proceder assim, está ainda a pisar o "terreno [...] da especulação" 58 . Uma investigadora da Universidade do Minho, Nadejda Ivanovna Nagovitsina Machado, retoma a questão, alargando-a, no entanto, à análise da novela "Asas" de Céu em Fogo, num ensaio bem documentado, com amplo recurso a bibliografia russa, vindo recentemente a lume na revista Diacrítica, "Linguagem e sentidos da vanguarda futurista. Ecos do Futurismo russo em Portugal"59. Quer num caso quer no outro, Nadjeda Machado faz incidir a sua análise sobre as teorias estéticas defendidas por personagens de uma e de outra narrativa, Gervásio Vila-Nova e o "Artista" russo Petrus Ivanovitch Zagorianski, as quais se aproximariam, em alguns aspectos,

57 Ib., p. 153.

58 Osvaldo Silvestre, op.cit., p. 96.

59 Nadejda Ivanovna Nagovitsina Machado, "Linguagem e sentidos da Vanguarda Futurista. Ecos do Futurismo Russo em Portugal”, Diacrítica - Revista do Centro de Estudos Humanísticos, Universidade do Minho, nº 21-3, 2007, pp. 125-144. 
das que eram propostas pelos futuristas russos, e não propriamente sobre os efeitos que elas teriam tido na prática poética de Sá-Carneiro, por exemplo. As semelhanças encontradas permitem à investigadora da Universidade do Minho, que não deixa de acentuar que as referidas teorias são atribuídas a personagens ficcionais e não podem, por tal motivo, ser assacadas ao autor, concluir por uma sintonia da parte de Mário de Sá-Carneiro relativamente às "correntes estéticas de vanguarda" ${ }^{60}$. Sem pôr em causa tal conclusão, ou, relativamente ao ensaio de Osvaldo Silvestre, a necessidade de atender ao dado aí posto em evidência, o da coincidência "ponto por ponto" entre a "definição do selvagismo" e "a transracionalidade dos poetas russos" ${ }^{1}$, a nós se nos afigura, no entanto, que o contributo do futurismo russo poderá não ser mais do que um contributo a par de outros, num poeta que a si próprio se via essencialmente como "doente-de-Novo"62 e que, no poema "Manucure", proclamava essa mesma magia do "Novo", no deslumbramento dos seus "olhos futuristas, $[\ldots]$ cubistas, $[. .$.$] interseccionis-$ tas" ${ }^{63}$. Se alguma estética é privilegiada neste poema é, aliás, a estética marinettiana das "Palavras em liberdade", dos "sons sem fio" ${ }^{4}$, da "nova sensibilidade tipográfica" 65 . Mas se considerarmos a obra de Sá-Carneiro na sua globalidade, não poderemos deixar de entrar em linha de conta com a tradição que Pessoa, num texto bem conhecido ${ }^{66}$, definiu

${ }^{60}$ Cf. Machado, op. cit., pp. 141-142.

61 Cf. Silvestre, op. cit., p. 96.

${ }^{62}$ Mário de Sá-Carneiro, Poemas Completos, ed. de Fernando Cabral Martins, Lisboa, Assírio \& Alvim, 1996, p. 46.

63 Ib., p. 59.

64 Ib., p. 66.

65 Ib., p. 63.

${ }^{66}$ Fernando Pessoa, Páginas Íntimas e de Auto-Interpretação, textos estastabelecidos e prefaciados por Georg Rudolf Lind e Jacinto do Prado Coelho, Lisboa, Ática, 1966, pp. 133-140. 
para o sensacionismo português: "Descendemos de três movimentos mais antigos - o simbolismo francês, o panteísmo transcendentalista português, e a baralhada de coisas sem sentido e contraditórias de que o futurismo, o cubismo e outros quejandos são expressões ocasionais, embora, para sermos exactos, descendamos mais do seu espírito do que da sua letra" ${ }^{67}$. Não obstante o tom depreciativo que Pessoa usa para se referir às correntes do "movimento moderno", a verdade é que o termo a que recorre no original em inglês, "jumble", a seus olhos não deixa de sugerir a ideia de fusão que elas operam nesse mesmo movimento, assim como, para Mário de Sá-Carneiro, em "Manucure", o "Novo" que o unge resulta da conjunção do futurismo, do cubismo e do interseccionismo.

O poema "Manucure" de Sá-Carneiro foi certamente, pela relevância que nele assume a dimensão visual da poesia, um ponto de referência para os experimentalistas portugueses na década de 60. Definindo uma corrente de neovanguarda que recolhe o legado das vanguardas históricas, o movimento da Poesia Experimental, ao acentuar essa visualidade, toma como lugares de passagem obrigatória "Un Coup de dés" de Mallarmé, os caligramas de Apollinaire, as "palavras em liberdade" dos futuristas, os poemas visuais dos dadaístas. E. M. de Melo e Castro, um dos mais activos teorizadores do experimentalismo português, inclui, no ensaio A Proposição 2.01 - A Poesia Experimental, vindo a público em 1965, as "experiências do Futurismo" no âmbito da "poesia visual", um dos tipos que enumera de "poesia experimental"68. Ora uma das heranças perceptíveis em alguma da poesia concreta portuguesa é precisamente a dos quadros de palavras em liberdade dos futuristas. A um visopoema

67 Ib., p 134.

${ }^{68}$ Cf. Ana Hatherly e E. M. de Melo e Castro, PO-EX: Textos Teóricos e Documentos da Poesia Experimental Portuguesa, Lisboa, Moraes, 1981, p. 115. 
como o de António Aragão incluído na Antologia da Poesia Concreta em Portugal ${ }^{69}$ podem, sem dificuldade, aplicar-se as palavras com que Aguiar e Silva, num capítulo de Teoria e Metodologia Literárias, se refere aos quadros de palavras em liberdade dos futuristas: "nestas composições, é abolida a linearidade do texto e a sintaxe fica reduzida a articulações mínimas entre elementos sintagmáticos disseminados no meio de grafismos não verbais e de elementos pictóricos" $" 70$. Ana Hatherly, autora de um estudo de referência sobre o nosso Futurismo, em que dá especial atenção ao "aspecto visual do texto", "Êxtase e herança - breve introdução ao futurismo português" "71, e cuja leitura há que complementar com a de um outro ensaio do mesmo livro, "Texto e visualidade" 72 , levará ainda mais longe a visualidade do signo linguístico nos seus "desenhos/ escritas", tornando, como diz no texto introdutório de Mapas da Imaginação e Memória, a sua própria escrita "ilegível"73, e, por essa mesma via, mais susceptível de se dar a ver em galerias ou museus.

O legado futurista, podemos concluir, foi fundamental na conformação da nossa modernidade poética, quer por via da celebração da civilização moderna, do seu dinamismo, ou da máquina e da fábrica, como tivemos ocasião de verificar em textos de António de Navarro, Gil Vaz, ou Joaquim Namorado, quer através da relevância conferida aos elementos visuais no poema, como pudemos observar nos poemas dimensionais de António Pedro ou nos visopoemas dos experimentalistas, quer ainda por via de uma possível aproxima-

69 Cf. Antologia da Poesia Concreta em Portugal, org. de José Alberto Marques e E.M. de Melo e Castro, Lisboa, Assírio \& Alvim, 1973, p. 48.

${ }^{70}$ Vítor Manuel de Aguiar e Silva, Teoria e Metodologia Literárias, Lisboa, Universidade Aberta, 1990, pp. 170-171.

71 Ana Hatherly, O Espaço Crítico - do Simbolismo à Vanguarda, Lisboa, Caminho, 1979 , pp. 55-75.

72 Ib., pp. 91-106.

73 Ana Hatherly, Mapas da Imaginação e da Memória, Lisboa, Moraes, 1973, p. 9. 
ção das experiências de desarticulação semântica da linguagem levadas a cabo por Jorge de Sena nos "Quatro sonetos a Afrodite Anadiómena" à linguagem transmental dos cubo-futuristas russos. Também a revolução tipográfica dos futuristas deixou marcas no nosso Modernismo, como pode ver-se em algumas das revistas que o promoveram, nomeadamente na presença, também a esse respeito bem integrada no espírito moderno. Poderia parecer estranha a atenção concedida a Almada e a Raul Leal, que não é possível encarar como posteridade de um movimento de que foram, afinal, destacados protagonistas, entre nós, na sua fase heróica. Mas a persistência de um e de outro ao longo dos anos em defesa da modernidade e num combate sem tréguas contra o passadismo e o academismo justificavam plenamente que a eles nos referíssemos. Lembrámos o Almada que, nos anos 30, vituperou, por um lado, a Marinetti a traição ao anti-academismo inicial, e, por outro, fez questão de sublinhar a "divergência" entre Arte e Política junto daqueles que seguiam o exemplo do poeta italiano na ligação do futurismo ao fascismo. E evocámos o Raul Leal defensor de heterodoxas "concepções ultrafuturistas", expostas na carta a Marinetti e em outros lugares, num estilo que procura adequar-se à "Vertigem labirintizante" do seu pensamento. 